\title{
Hydrous origin of the continental cratonic mantle
}

\author{
Kyoko N Matsukage ${ }^{1 *}$ and Toshisuke Kawasaki
}

\begin{abstract}
We performed melting experiments of hydrous pyrolite at pressures from 3 to $8 \mathrm{GPa}$ and temperatures from $1,100^{\circ} \mathrm{C}$ to $1,800^{\circ} \mathrm{C}$ to identify the origin of chemical variation in cratonic garnet peridotites with high contents of magnesian orthopyroxene. In hydrous conditions, the stability field of residual orthopyroxene expands relative to olivine above solidus, and the harzburgitic residue contains large amounts of Mg-rich (Mg\# > 0.92) orthopyroxene at 4.5 to $6 \mathrm{GPa}$. The residual chemistry obtained from our experiments indicates that the chemical variation of the cratonic garnet peridotites possibly reflects formation by melt depletion under various water contents from almost anhydrous to a maximum of approximately $1 \%$ to $2 \%$ in the upper mantle at depths of about 100 to $200 \mathrm{~km}$.
\end{abstract}

Keywords: Cratonic mantle; Peridotite; Hydrous pyrolite; Partial melting; Residue; High-pressure experiment

\section{Findings \\ Introduction}

Partial melting and melt extraction in the upper mantle is a well-known process that causes radial and lateral variations in the chemistry. Abyssal mantle peridotites are a good example of simple residues. The chemical variation shows good agreement with results of experimental and theoretical studies of partial melting and melt extraction processes from a primitive lherzolite at depths of $<80 \mathrm{~km}(P \cong 2.5 \mathrm{GPa})$ (e.g., Dick et al. 1984; Arai 1994; Matsukage and Kubo 2003). Based on the chemical composition of the residual oceanic peridotites, Ringwood (1966) proposed a hypothetical primitive mantle termed pyrolite. For many years, pyrolite has been regarded as a common model for Earth's primitive mantle. Peridotite xenoliths, which were transported by kimberlite magma from the deep upper mantle (approximately $250 \mathrm{~km}$ ) under Archean continental cratons, differ greatly in chemistry from shallow oceanic mantle (e.g., Boyd 1989). The cratonic mantle peridotites are characterized by a large amount of $\mathrm{SiO}_{2}$ in combination with a high $\mathrm{Mg} /(\mathrm{Mg}+\mathrm{Fe})$ ratio. Despite the considerable number of studies conducted to explore the origin of the unusual cratonic peridotites, their origin remains controversial (e.g., Pearson and Wittig 2013). Based on the melting experiments of the pyrolite- $\mathrm{H}_{2} \mathrm{O}$ system at high pressure, we demonstrate

\footnotetext{
* Correspondence: kmatsu@gaia.h.kyoto-u.ac.jp

${ }^{1}$ Graduate School of Human and Environmental Studies, Kyoto University,

Yoshida-Nihonmatsu-cho, Sakyo-ku, Kyoto 606-8501, Japan

Full list of author information is available at the end of the article
}

the possibility that the $\mathrm{Si}$ - and $\mathrm{Mg}$-rich cratonic peridotites originated as simple melting residues under hydrous conditions at depths of approximately 100 to $200 \mathrm{~km}$.

\section{Chemical and modal variations of continental cratonic peridotites}

Figure 1 presents chemical variations of abyssal peridotites and continental cratonic peridotites. The abyssal mantle peridotites are characterized by a monotonous chemical and modal trend, which are depleted in $\mathrm{SiO}_{2}$, $\mathrm{Al}_{2} \mathrm{O}_{3}$, and $\mathrm{CaO}$, but have increased $\mathrm{MgO}$ (Figure 1a,b). The abyssal peridotites show a wide lithological variation, from lherzolite with more than $15 \%$ of clinopyroxene to harzburgite without clinopyroxene. The amount of olivine increases from $60 \%$ to $85 \%$ with the lithological change from lherzolite to harzburgite (e.g., Dick et al. 1984). In addition, the amount of compatible elements increases concomitantly with increasing modal proportion of olivine (Figure 1d). If the pyrolitic lherzolite partially melts within the plagioclase or spinel stability fields, clinopyroxene is preferentially molten relative to olivine and orthopyroxene, and the residual rock type changes from lherzolite to harzburgite with increasing degrees of partial melting (Baker and Stolper 1994; Matsukage and Kubo 2003). At the same time, the residual minerals are depleted in incompatible elements. The trends of chemical variation in abyssal peridotites are consistent with the theoretical and experimental observations of the residues obtained by partial melting of pyrolitic lherzolite at shallow upper mantle depths. 

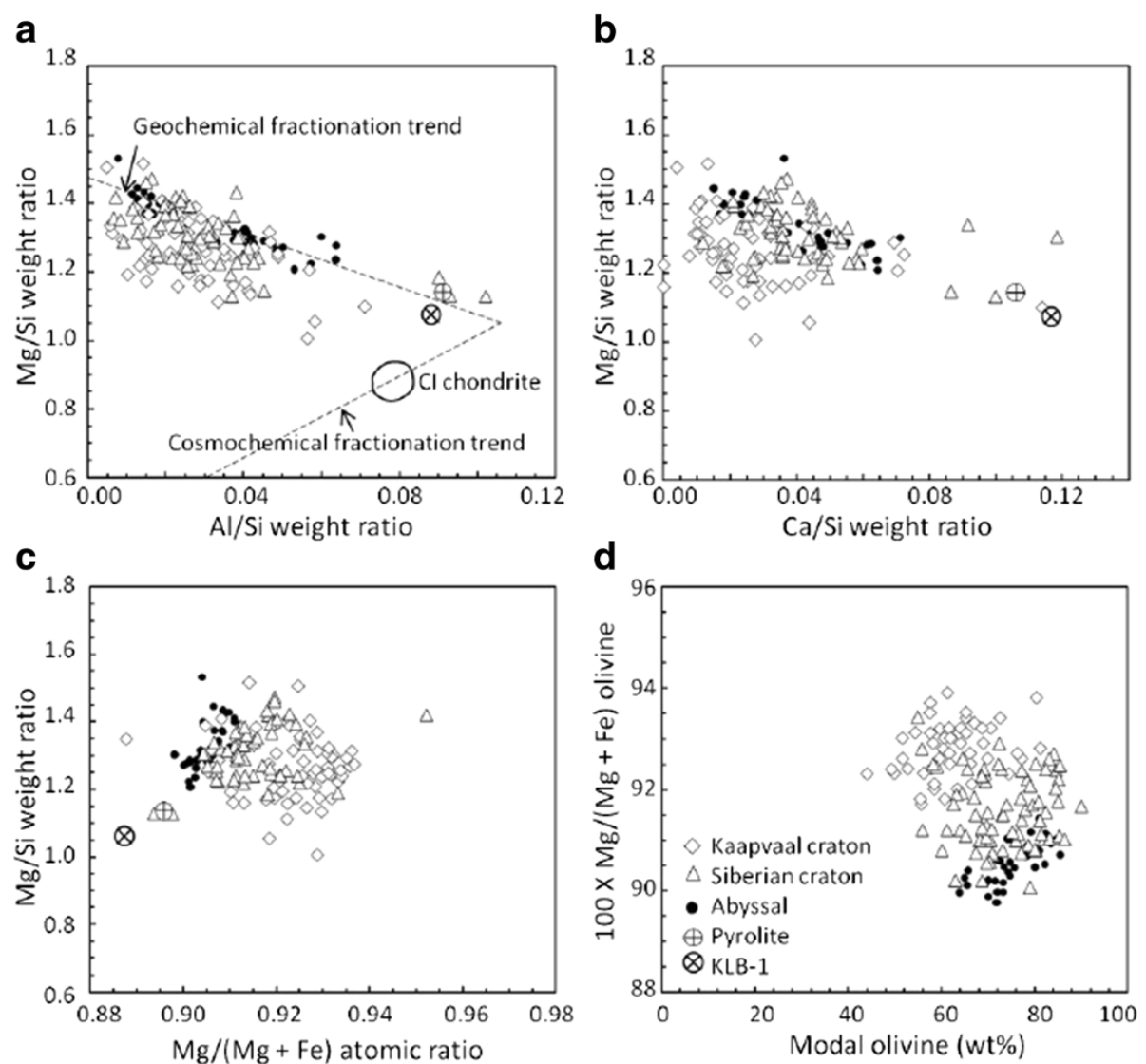

Figure 1 Bulk chemistry $(a, b, c)$ and relation between $\mathrm{Mg} /(\mathbf{M g}+\mathrm{Fe})$ (atomic percent) and modal compositions of olivine (d). They are in abyssal and continental cratonic peridotites. Data for abyssal peridotites are after Michael and Bonatti (1985), Dick (1989), Dick and Natland (1996), Arai and Matsukage (1996), and Matsukage et al. (2005). Data for the Kaapvaal and Siberian cratons are after Nixon and Boyd (1973), Cox et al. (1973), Carswell et al. (1979), Boyd et al. (1993), Boyd et al. (1997), Gibson et al. (2008), Katayama et al. (2009), Goncharov et al. (2012), and Doucet et al. (2013). Cl chondrite, geochemical fractionation trend, and cosmochemical fractionation trend are referred from Jagoutz et al. (1979).

Both garnet and spinel peridotites are found frequently in continental regions (e.g., Hervig et al. 1980; Boyd et al. 1997). In off-craton continental regions, chemical and modal variations of most spinel peridotites show a trend similar to that of abyssal peridotites. This similarity is interpreted as being due to the partial melting and melt extraction processes of pyrolitic lherzolite. In contrast, some of the cratonic garnet and spinel peridotites have widely scattered chemical variations (e.g., Boyd 1989; Doucet et al. 2012). Figure 1 shows the bulk chemistries of garnet-bearing peridotites from the Kaapvaal craton and the Siberian craton. The peridotites in the Kaapvaal craton contain a large amount of orthopyroxene (e.g., Boyd 1989). It is especially remarkable that some peridotites with $\mathrm{Mg \#}$ of more than 0.92 contain up to 45 vol.\% of orthopyroxene (Nixon and Boyd 1973). The Siberian craton also shows slight enrichments in $\mathrm{SiO}_{2}$ (=orthopyroxene) in garnet peridotites (e.g., Boyd et al. 1997; Doucet et al. 2013). Another important feature of the cratonic garnet peridotite is that the olivine

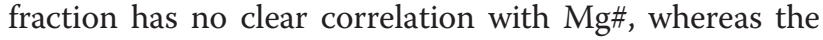
abyssal peridotite indicates a clear positive correlation between the amount of olivine and the Mg\# (Figure 1d). Walter (1998) pointed out that the composition of cratonic peridotites cannot be explained by partial melting of pyrolitic lherzolite alone in any depth of the upper mantle. Some process of adding an orthopyroxene component to the system is needed. The high Mg\# implies a high degree of partial melting and melt extraction. Melting experiments of pyrolitic lherzolite from surface pressures to $7 \mathrm{GPa}$, however, have demonstrated that the $\mathrm{SiO}_{2}$ content of the residue should always be lower than pyrolite (Walter 1998).

Four models have been proposed to explain the high orthopyroxene concentration. The first model suggests that the high degree of melting at higher pressure produced the high Mg\# and intermediate amount of orthopyroxene (about 25 vol.\%) residue. Then metamorphic differentiation or sorting during cumulate formation unmixed the orthopyroxene-rich (more than $40 \mathrm{vol. \%}$ ) and 
orthopyroxene-poor segregations (Boyd et al. 1997). The second model proposes that the cratonic peridotites are mixtures of residues of high degrees of partial melting and melt extraction from pyrolitic lherzolite with high Mg\# and low orthopyroxene content and higher pressure igneous cumulates with high opx/olivine ratios (Herzberg 1999). The third model is similar to the second, but the mechanism of $\mathrm{SiO}_{2}$ addition (orthopyroxene addition) differs. In this model, the cratonic peridotites are regarded as being produced by the reaction between previously highly depleted low orthopyroxene residue and $\mathrm{SiO}_{2}$-rich liquid that is generated mainly by partial melting of eclogitic basalt and sediment in a subduction zone (Kelemen et al. 1998). In all three models, the formation of the cratonic peridotites involves a process (or several processes) of Si addition other than simple partial melting. The fourth model proposes that the cratonic peridotites are the residues of high degrees of partial melting of a mantle enriched in $\mathrm{SiO}_{2}$ related to pyrolite (Walter 1998). $\mathrm{CI}$ chondrite mantle is one of the candidates for the $\mathrm{Si}$ rich primitive mantle.

We propose yet another model for the formation of the $\mathrm{SiO}_{2^{-}}$and MgO-rich cratonic peridotites, based on our melting experiments of the pyrolitic lherzolite $+\mathrm{H}_{2} \mathrm{O}$ system. Previous melting experiments in the simplified hydrous pyrolite systems, such as $\mathrm{MgO}-\mathrm{SiO}_{2}-\mathrm{H}_{2} \mathrm{O}$ and $\mathrm{MgO}-\mathrm{SiO}_{2}-\mathrm{CaO}-\mathrm{Al}_{2} \mathrm{O}_{3}-\mathrm{H}_{2} \mathrm{O}$ systems (e.g., Inoue 1994; Mibe et al. 2002; Litasov and Ohtani 2002; Kawamoto et al. 2004), have demonstrated that the chemical composition of partial melts (and aqueous fluids which coexist with mantle minerals) changes rapidly from $\mathrm{SiO}_{2}$-rich to $\mathrm{MgO}$-rich with increasing pressure above $3 \mathrm{GPa}$. These experimental observations suggest that the Si-rich cratonic peridotites could have formed as melting residues without the need for secondary Si addition. We report the melting experiments of hydrous pyrolite with multiple components and compare the chemical trends of the residues obtained in these experiments with those of natural cratonic peridotites.

\section{Experimental methods \\ Starting materials}

We synthesized the hydrous pyrolite in the $\mathrm{SiO}_{2}-\mathrm{Al}_{2} \mathrm{O}_{3}$ $\mathrm{CaO}-\mathrm{FeO}-\mathrm{MgO}-\mathrm{TiO}_{2}-\mathrm{Cr}_{2} \mathrm{O}_{3}-\mathrm{Na}_{2} \mathrm{O}-\mathrm{K}_{2} \mathrm{O}-\mathrm{NiO}-\mathrm{H}_{2} \mathrm{O}$ system. Table 1 lists the pyrolite composition (Ringwood 1966) and the starting materials for melting experiments in this study. Powders of reagent grade $\mathrm{SiO}_{2}, \mathrm{Al}_{2} \mathrm{O}_{3}$, $\mathrm{CaCO}_{3}, \mathrm{Fe}_{2} \mathrm{O}_{3}, \mathrm{TiO}_{2}, \mathrm{Cr}_{2} \mathrm{O}_{3}, \mathrm{Na}_{2} \mathrm{CO}_{3}, \mathrm{~K}_{2} \mathrm{CO}_{3}$, and $\mathrm{NiO}$ were mixed and decarbonated in a 1-atm electric furnace at $1,000^{\circ} \mathrm{C}$ for $24 \mathrm{~h}$ in the air. After decarbonation, the charge was fused at $1,500^{\circ} \mathrm{C}$ in the reducing furnace under controlling oxygen fugacity to QFM (quartzfayalite-magnetite) buffer using the mixed gas $\left(\mathrm{CO}_{2}\right.$ and $\mathrm{H}_{2}$ ) flow technique (Kawasaki 2001). We confirmed
Table 1 Chemical compositions of pyrolite and starting materials

\begin{tabular}{|c|c|c|c|}
\hline & \multirow{2}{*}{ Pyrolite $^{a}$} & \multicolumn{2}{|c|}{$\mathrm{H}_{2} \mathrm{O}$} \\
\hline & & 2 wt.\% & 8 wt.\% \\
\hline $\mathrm{SiO}_{2}$ & 45.16 & 44.55 & 41.82 \\
\hline $\mathrm{TiO}_{2}$ & 0.71 & 0.56 & 0.53 \\
\hline $\mathrm{Al}_{2} \mathrm{O}_{3}$ & 3.54 & 3.14 & 2.95 \\
\hline $\mathrm{Cr}_{2} \mathrm{O}_{3}$ & 0.43 & 0.42 & 0.40 \\
\hline $\mathrm{FeO}^{*}$ & 8.47 & 8.05 & 7.56 \\
\hline $\mathrm{MnO}$ & 0.14 & & \\
\hline $\mathrm{MgO}$ & 37.48 & 36.82 & 34.56 \\
\hline $\mathrm{CaO}$ & 3.08 & 2.96 & 2.78 \\
\hline $\mathrm{Na}_{2} \mathrm{O}$ & 0.57 & 1.19 & 1.11 \\
\hline $\mathrm{K}_{2} \mathrm{O}$ & 0.13 & 0.17 & 0.16 \\
\hline $\mathrm{P}_{2} \mathrm{O}_{5}$ & 0.06 & & \\
\hline $\mathrm{NiO}$ & 0.20 & 0.14 & 0.13 \\
\hline $\mathrm{H}_{2} \mathrm{O}$ & & 2.00 & 8.00 \\
\hline Total & 99.97 & 100.00 & 100.00 \\
\hline $\mathrm{Mg} \#^{\mathrm{b}}$ & 0.887 & 0.891 & 0.891 \\
\hline
\end{tabular}

${ }^{\mathrm{a} A f t e r}$ Ringwood (1966); ${ }^{\mathrm{b}} \mathrm{Mg} /(\mathrm{Mg}+\mathrm{Fe})$ atomic ratio; $\mathrm{FeO}^{*}$, total iron is listed as $\mathrm{FeO}$.

that the quenched glass was chemically homogeneous from SEM-EDS (scanning electron microprobe analyzer (JSR1000, JEOL, Tokyo, Japan) with energy dispersive spectrometer (Oxford Instruments, Oxfordshire, UK)) observations. The amount of $\mathrm{CO}_{2}$ remaining in the glass was measured via Fourier transform infrared spectroscopy. $\mathrm{No} \mathrm{CO}_{2}$ peaks were detected, which indicates that $\mathrm{CO}_{2}$ was not included in the glass. The glass was ground again and mixed with a powder of periclase $(\mathrm{MgO})$ and brucite $\left(\mathrm{Mg}(\mathrm{OH})_{2}\right)$ to adjust the water contents of the starting material to 2 and $8 \mathrm{wt} . \%$, respectively.

\section{Experiments at high pressure and high temperature}

High-pressure and high-temperature experiments were conducted using a Kawai-type multi-anvil apparatus installed at Ehime University, Japan, with an $18 \mathrm{M} / 11$ cell assembly (Figure 2) at pressures from 3 to $8 \mathrm{GPa}$, and temperatures from $1,100^{\circ} \mathrm{C}$ to $1,800^{\circ} \mathrm{C}$ (Table 2). Pressure was generated by eight $26-\mathrm{mm}$ tungsten carbide anvils with an 11-mm truncated edge length. A Co-doped semi-sintered $\mathrm{MgO}$ octahedron with an 18-mm edge length was used as a pressure-transmitting medium. A graphite sleeve was used as the heater. To reduce the temperature gradient, a graphite heater was placed within a $\mathrm{LaCrO}_{3}$ thermal insulation sleeve. We adopted the double capsule technique. The starting materials were put in an inner Re capsule which was inserted into the outer Pt capsule (Matsukage and Kubo 2003). In some of the experiments at low temperatures and long durations, we 


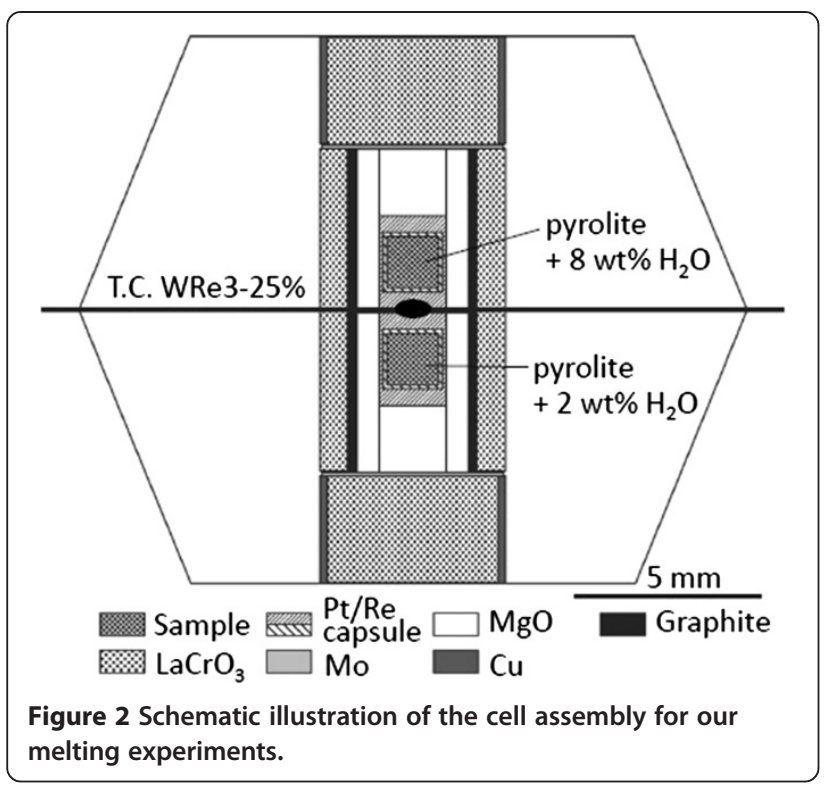

used an $\mathrm{Au}_{75} \mathrm{Pd}_{25}$ single capsule as a sample container (Hirose and Kawamoto 1995) (Table 2). Two edges of the outer Pt capsule and the single $\mathrm{Au}_{75} \mathrm{Pd}_{25}$ capsule were welded to provide mechanical sealing for hydrous melt. Loss of Fe from the sample to the Re/Pt double capsule and $\mathrm{Au}_{75} \mathrm{Pd}_{25}$ capsules is less than $2 \%$ in the experimental conditions listed in Table 2, except for OD1084. The sample containers were insulated electrically from the furnace by an enclosure in an $\mathrm{MgO}$ sleeve and were placed in the central part of the furnace (Figure 2). High-pressure experiments were carried out as follows: First, we compressed the sample to the target pressure, then heated it to the target temperature and kept it under constant oil pressure for 30 to $420 \mathrm{~min}$. After being kept at the desired pressure and temperature for the desired duration, the samples were quenched by cutting off the electric power supply. The pressure was then released slowly, at about $1 \mathrm{GPa} / \mathrm{h}$, and the experiment products were recovered. The run products were sectioned longitudinally and polished for chemical analysis. The pressure and temperature for each experiment were estimated through pressure-load calibration and through a thermocouple reading. Pressure-load relations were presented by Matsukage et al. (2013). The temperature was measured using a $W_{3} \operatorname{Re}-W_{25} \operatorname{Re}$ thermocouple. The temperature gradient in the capsule was estimated at about $60^{\circ} \mathrm{C}$ using a two-pyroxene thermometer (Gasparik 1990).

\section{Chemical analysis and calculation of bulk chemistry of residue}

Chemical composition of residual minerals and quenched partial melts were analyzed using SEM-EDS. The chemical

Table 2 Run conditions and results of experiments on hydrous pyrolite

\begin{tabular}{|c|c|c|c|c|c|}
\hline \multirow[t]{2}{*}{ Run no. } & \multirow{2}{*}{$\begin{array}{c}\text { Pressure } \\
\text { (GPa) }\end{array}$} & \multirow{2}{*}{$\begin{array}{c}\text { Temperature } \\
\left({ }^{\circ} \mathrm{C}\right)\end{array}$} & \multirow{2}{*}{$\begin{array}{l}\text { Duration } \\
\text { (min) }\end{array}$} & \multicolumn{2}{|c|}{ Run products } \\
\hline & & & & 2 wt. $\% \mathrm{H}_{2} \mathrm{O}$ & 8 wt. $\% \mathrm{H}_{2} \mathrm{O}$ \\
\hline OD1085 & 3.0 & 1,200 & 180 & $\mathrm{Ol}, \mathrm{MgPx}, \mathrm{L}$ & $\mathrm{Ol}, \mathrm{MgPx}, \mathrm{L}$ \\
\hline OD1083 & 3.0 & 1,400 & 180 & $\mathrm{Ol}, \mathrm{L}$ & L \\
\hline OD1094 & 3.0 & 1,490 & 30 & $\mathrm{Ol}, \mathrm{L}$ & \\
\hline OD1084 & 3.0 & 1,600 & 60 & $L$ & L \\
\hline OD1022 & 4.5 & 1,200 & 180 & Ol, MgPx, Gt, L & $\mathrm{Ol}, \mathrm{MgPx}, \mathrm{Gt}, \mathrm{L}$ \\
\hline OD1053 & 4.5 & 1,300 & 420 & Ol, MgPx, Gt, L, FeTi & Ol, MgPx, L, FeTi \\
\hline OD1050 & 4.5 & 1,400 & 120 & $\mathrm{Ol}, \mathrm{MgPx}, \mathrm{L}$ & $\mathrm{Ol}, \mathrm{MgPx}, \mathrm{L}$ \\
\hline OD1045 & 4.5 & 1,490 & 30 & Ol, MgPx, L & $\mathrm{Ol}, \mathrm{L}$ \\
\hline OD1082 & 4.5 & 1,600 & 60 & $\mathrm{Ol}, \mathrm{L}$ & $\mathrm{L}$ \\
\hline OD1087 & 4.5 & 1,700 & 30 & $\mathrm{~L}$ & \\
\hline OD1080 & 6.0 & 1,100 & 360 & $\mathrm{Ol}, \mathrm{MgPx}, \mathrm{Gt}, \mathrm{CaPx}, \mathrm{L}, \mathrm{FeTi}$ & Ol, MgPx, Gt, L, FeTi \\
\hline OD1065 & 6.0 & 1,400 & 420 & Ol, MgPx, Gt, L, FeTi & MgPx, Gt, L, FeTi \\
\hline OD1079 & 6.0 & 1,500 & 120 & Ol, MgPx, Gt, L & MgPx, L \\
\hline OD1063 & 6.0 & 1,600 & 60 & $\mathrm{Ol}, \mathrm{MgPx}, \mathrm{Gt}, \mathrm{L}$ & $L$ \\
\hline OD1095 & 6.0 & 1,700 & 30 & $\mathrm{Ol}, \mathrm{L}$ & \\
\hline OD1092 & 6.0 & 1,780 & 30 & $\mathrm{~L}$ & \\
\hline OD1088 & 6.0 & 1,800 & 30 & L & \\
\hline OD1086 & 8.0 & 1,500 & 60 & $\mathrm{Ol}, \mathrm{MgPx}, \mathrm{CaPx}, \mathrm{Gt}, \mathrm{L}$ & $\mathrm{MgPx}, \mathrm{Gt}, \mathrm{L}$ \\
\hline OD1058 & 8.0 & 1,600 & 48 & Ol, MgPx, Gt, L & L \\
\hline
\end{tabular}

$\mathrm{Ol}$, olivine; MgPx, Mg-rich orthopyroxene; Gt, garnet; $\mathrm{CaPx}$, clinopyroxene; FeTi, Fe- and Ti-bearing hydroxide; L, liquid; ${ }^{\mathrm{a} U s i n g ~} \mathrm{Au}_{75} \mathrm{Pd}_{25} \mathrm{capsule}$ 

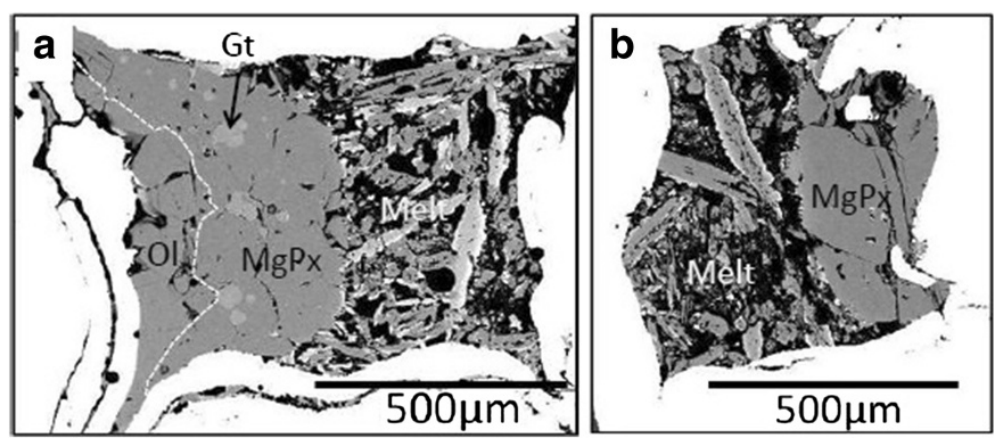

Figure 3 Back-scattered electron images. (a) Pyrolite +2 wt. $\% \mathrm{H}_{2} \mathrm{O}$ and (b) pyrolite +8 wt.\% $\mathrm{H}_{2} \mathrm{O}$ at $6 \mathrm{GPa}$ and 1,500 ${ }^{\circ} \mathrm{C}(\mathrm{OD} 1079)$.

analyses were performed with a $15-\mathrm{kV}$ accelerating voltage, 8.5-nA beam current, an integration counting time of $100 \mathrm{~s}$, and a working distance of $20 \mathrm{~mm}$ with ZAF correction. Standards used were wollastonite for $\mathrm{Si}$ and $\mathrm{Ca}$, rutile for $\mathrm{Ti}$, corundum for $\mathrm{Al}$, chromian spinel for $\mathrm{Cr}$, hematite for $\mathrm{Fe}$, periclase for $\mathrm{Mg}$, and albite for $\mathrm{Na}$. The quenched melts show a mixture of quenched crystals and glasses. We found that the melts segregated from the residual minerals to form a melt pool in the capsule recovered from high-pressure and high-temperature experiments. Therefore, the mixtures of quenched glass and quenched crystal were analyzed by beam scanning across $15 \times 15 \mu \mathrm{m}$ to $200 \times 200 \mu \mathrm{m}$ raster areas depending on the melt pool size. A focused beam was chosen for the analysis of residual minerals because the residual minerals are chemically homogeneous.

For the experiments with 2 wt.\% $\mathrm{H}_{2} \mathrm{O}$, the modal composition of residual minerals $\left(M^{j}\right)$ and the degree of melting $\left(M^{\text {melt }}\right)$ were determined through mass balance calculation: $\sum_{i}\left[\left(X^{i, \mathrm{sm}}-\left(M^{\text {melt }} X^{i, \text { melt }}+\sum_{j} M^{j} \cdot X^{i, j}\right)\right]^{2}=\right.$ minimum, where $X^{i, \mathrm{sm}}, X^{i, \text { melt }}$, and $X^{i, j}$ denote the weight percentages of components $i$ in the starting material, partial melt, and residual minerals $j$ in run products, respectively. The bulk chemistry of the residue $\left(X^{i, r}\right)$ was calculated using the following equation: $X^{i, r}=\sum_{j} N^{j} X^{i, j}$, where $N^{j}$ is the weight ratio of minerals in residue, given as $N^{j}=M^{j} /\left(1-M^{\text {melt }}\right)$. We assumed that water was distributed within the liquid phase in this calculation because the solubility of $\mathrm{H}_{2} \mathrm{O}$ in the residual minerals is lower than approximately $0.1 \mathrm{wt} . \%$ in the experimental conditions.

\section{Results and discussion}

We found that all run products included a liquid phase. Residual minerals were homogeneous in chemistries, and grew in a round shape. The average grain sizes were larger than approximately $50 \mu \mathrm{m}$. The partial melts were distributed in grain boundaries of the residual minerals in addition to the segregated melt pool (Figures 3 and 4), and the interstitial melts and segregation melts were interconnected in all run products. The experiments with 2 wt.\% $\mathrm{H}_{2} \mathrm{O}$ showed that the residual mineral assemblage was olivine + orthopyroxene + garnet + clinopyroxene at lower temperatures. The solid phases dissolved to liquid in the following order, clinopyroxene, garnet,

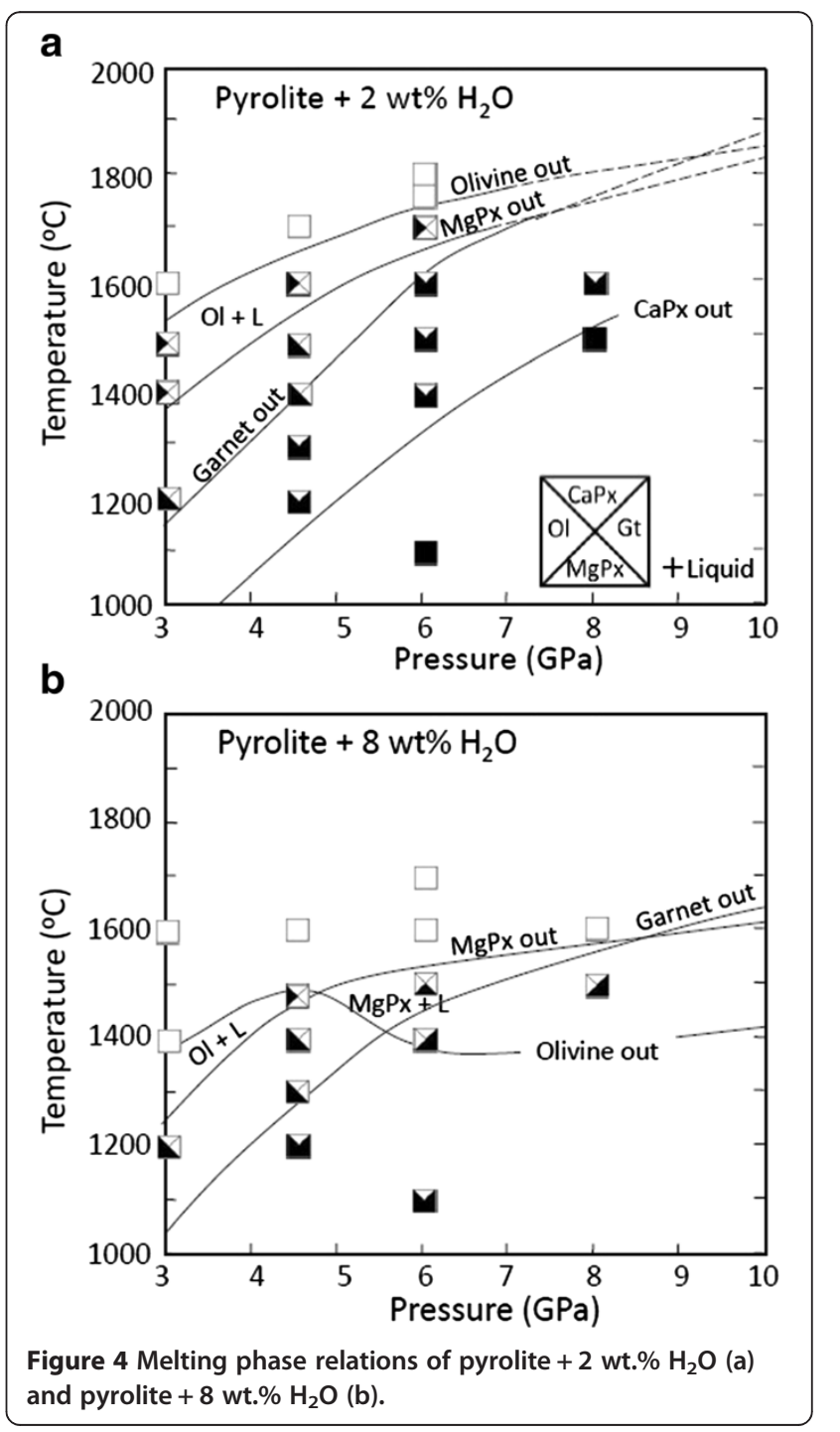


orthopyroxene, and olivine below 6 GPa. Therefore, the rock type corresponding to the residue changes from garnet lherzolite to dunite through garnet-bearing and garnet-free harzburgite with increasing temperature (Figure 4a). The garnet-bearing harzburgite contains a large amount of orthopyroxene with approximately $40 \%$ of modal abundance in residue at pressures between 4.5 and $6 \mathrm{GPa}$ (Figure 3a, Table 3). These garnet harzburgites contain olivine and orthopyroxene with high Mg\# of more than 0.92 (Table 3). Our experiments demonstrated that the amount of orthopyroxene in hydrous conditions is always higher than that in dry conditions. The partial melts are similar to komatiite, which is characterized by a low $\mathrm{SiO}_{2}$ (approximately 45 wt.\%) and high $\mathrm{MgO}$ content (>18 wt.\%). In our experiments, the $\mathrm{Al}_{2} \mathrm{O}_{3}$ content of the partial melts were systematically reduced with increasing pressure (Table 3 ). In the experiments of $8 \mathrm{wt} . \% \mathrm{H}_{2} \mathrm{O}$, the stability field of olivine shrinks with increasing pressure and the residual rock type changes from harzburgite to orthopyroxenite through garnet-bearing orthopyroxenite with increasing temperatures above $6 \mathrm{GPa}$ (Figures $3 \mathrm{~b}$ and $4 \mathrm{~b}$ ). The $\mathrm{Mg} \#$ of residual olivine, orthopyroxene, and garnet is comparable or slightly higher than that with $2 \mathrm{wt} \%$ $\mathrm{H}_{2} \mathrm{O}$ (Table 4). In the recovered sample of the experiment with 8 wt.\% $\mathrm{H}_{2} \mathrm{O}$, the grain boundaries of quenched crystals or quenched glasses opened, and loss of much of the quenched crystals and quenched glasses occurred when the samples were polished. Because of this, the reliable composition of the partial melts could not be measured. The expansion of the stability field of orthopyroxene relative to olivine above solidus has been reported in the simplified hydrous systems at high pressures above $3 \mathrm{GPa}$ (e.g., Inoue 1994; Ohtani et al. 1996; Mibe et al. 2002; Litasov and Ohtani 2002; Kawamoto et al. 2004). Our result shows that the results of previous studies are also realized in the pyrolitic lherzolite with multiple components.

Figure 5 shows the calculated bulk chemistry of residues with 2 wt.\% $\mathrm{H}_{2} \mathrm{O}$, which is compared with those in anhydrous conditions obtained in previous studies (Walter 1998; Matsukage and Kubo 2003). Under anhydrous conditions, the $\mathrm{Al} / \mathrm{Si}$ and $\mathrm{Ca} / \mathrm{Si}$ ratios of residues increase with increasing pressure because the stability field of garnet expands at higher pressure. At lower pressures $(\leq 2.5 \mathrm{GPa})$, the stable aluminous phase in peridotites is spinel, which reacts with orthopyroxene and clinopyroxene to form a garnet + olivine assemblage at higher pressures. The residue in the garnet stability field is characterized by higher amounts of Al-bearing minerals, such as garnet and aluminous pyroxenes (Baker and Stolper 1994; Walter 1998). The residual trends in hydrous conditions differ from those in anhydrous conditions (Figure 5). They show a lower $\mathrm{Mg} / \mathrm{Si}$ ratio and a higher $\mathrm{Mg} \#$. From 3 to $6 \mathrm{GPa}$, the $\mathrm{Mg} / \mathrm{Si}$ ratio decreases and $\mathrm{Mg \#}$ increases systematically. It is remarkable that the $\mathrm{SiO}_{2}$ content of the residual garnet-bearing harzburgite is higher than that of pyrolitic lherzolite (Walter $1998)$ at 4.5 to $6 \mathrm{GPa}$. These harzburgite residues contain high amounts of orthopyroxene of up to $58 \%$ in modal abundance. Moreover, the bulk Mg\#s are higher than 0.92. Figure 5 shows that the residual trends obtained in our experiments are consistent with the chemical variations of $\mathrm{SiO}_{2}$-rich and $\mathrm{MgO}$-rich cratonic peridotites. Consequently, we propose that the chemical difference between the abyssal and the $\mathrm{SiO}_{2}$-rich cratonic peridotites are due to different water contents and the depth of melting during their melt depletion histories. The compositions of $\mathrm{SiO}_{2}$-rich cratonic garnet peridotites can be explained as having been formed under hydrous conditions in the upper mantle at depths of more than about $100 \mathrm{~km}$ (>3 GPa), whereas the most abyssal peridotites have likely formed under anhydrous conditions in the shallower upper mantle at depths of less than approximately $80 \mathrm{~km}$ within the spinel stability field.

If our model is correct, the Earth's mantle can be regarded as having spatial heterogeneity in water content at an early stage of the Earth's history. When comparing with the garnet peridotites in the Kaapvaal craton, those of the Siberian craton generally have higher $\mathrm{Mg} / \mathrm{Si}$ and lower Mg\# (Figure 1) (e.g., Boyd et al. 1997; Doucet et al. 2013). The equilibrium pressure of garnet peridotite xenoliths calculated using the olivine-garnet-orthopyroxene geothermobarometer shows that Siberian garnet peridotite xenoliths were derived from up to about $7 \mathrm{GPa}$ (e.g., Goncharov et al. 2012; Doucet et al. 2013), which is almost identical to those of southern Africa (e.g., Kawasaki 1987). Therefore, the chemical difference between the Kaapvaal craton and the Siberian craton could not be originated by a difference of the depth of melting. We infer that the almost water-free or lower water content during partial melting might be a major cause of higher $\mathrm{Mg} / \mathrm{Si}$ and lower Mg\# of Siberian garnet peridotites. In the Kaapvaal craton, the $\mathrm{Mg} / \mathrm{Si}$ ratio and $\mathrm{Mg \#}$ are highly scattered, and not all harzburgites are high in $\mathrm{SiO}_{2}$ content (Figure 1a,c). Consequently, the water contents might be scattered from almost anhydrous to a maximum of approximately $1 \%$ to $2 \%$ in this area. It is difficult to identify a geological environment for the formation of Si-rich and Mg-rich cratonic residues; a subduction zone would be a candidate for the geological environment because there needs to be a continuous supply of water in order to attain such a high degree of melting in hydrous conditions. We also speculate that the orthopyroxene-rich mantle may be formed at deep mantle wedges in the present Earth because water is being dragged into the deep mantle wedge by subducting slabs. 
Table 3 Modal and chemical compositions of experimental liquid and residual mineral phases in pyrolite +2 wt.\% $\mathrm{H}_{2} \mathrm{O}$

\begin{tabular}{|c|c|c|c|c|c|c|c|c|c|c|c|c|c|}
\hline Run no. & & Mode (wt.\%) & $\mathrm{SiO}_{2}$ (wt.\%) & $\mathrm{TiO}_{2}$ & $\mathrm{Al}_{2} \mathrm{O}_{3}$ & $\mathrm{Cr}_{2} \mathrm{O}_{3}$ & $\mathrm{FeO}^{*}$ & $\mathrm{MgO}$ & $\mathrm{CaO}$ & $\mathrm{Na}_{2} \mathrm{O}$ & $\mathrm{K}_{2} \mathrm{O}$ & Total & Mg\# \\
\hline \multicolumn{14}{|l|}{$3.0 \mathrm{GPa}$} \\
\hline \multirow[t]{3}{*}{ OD1085 } & $\mathrm{Ol}$ & 32 & 40.3 & 0.0 & 0.0 & 0.1 & 8.0 & 50.0 & 0.1 & 0.7 & 0.0 & 99.4 & 0.917 \\
\hline & $\mathrm{MgPx}$ & 21 & 56.1 & 0.0 & 1.4 & 0.9 & 5.1 & 35.1 & 0.3 & 0.8 & 0.0 & 99.7 & 0.925 \\
\hline & L (100\%) & 48 & 43.7 & 1.1 & 7.8 & 0.5 & 9.9 & 28.8 & 6.6 & 1.3 & 0.3 & 100.0 & 0.838 \\
\hline \multirow[t]{2}{*}{ OD1083 } & $\mathrm{Ol}$ & 31 & 40.6 & 0.0 & 0.0 & 0.2 & 6.1 & 52.3 & 0.1 & 0.7 & 0.0 & 100.1 & 0.938 \\
\hline & L (100\%) & 69 & 47.1 & 0.8 & 5.6 & 0.5 & 8.9 & 30.9 & 4.6 & 1.3 & 0.4 & 100.0 & 0.861 \\
\hline \multirow[t]{2}{*}{ OD1094 } & $\mathrm{Ol}$ & 29 & 42.1 & 0.0 & 0.0 & 0.1 & 5.9 & 53.3 & 0.1 & 0.0 & 0.0 & 101.5 & 0.942 \\
\hline & L (100\%) & 71 & 46.9 & 0.7 & 5.6 & 0.5 & 9.3 & 31.6 & 4.6 & 0.4 & 0.3 & 100.0 & 0.858 \\
\hline OD1084 & L (100\%) & 100 & 46.1 & 0.6 & 5.5 & 0.4 & 4.6 & 37.4 & 3.8 & 1.4 & 0.3 & 100.0 & 0.935 \\
\hline \multicolumn{14}{|l|}{$4.5 \mathrm{GPa}$} \\
\hline \multirow[t]{4}{*}{ OD1022 } & $\mathrm{Ol}$ & 39 & 40.3 & 0.0 & 0.0 & 0.1 & 8.4 & 48.9 & 0.0 & 0.2 & 0.0 & 97.9 & 0.912 \\
\hline & $\mathrm{MgPx}$ & 30 & 56.9 & 0.1 & 1.1 & 0.4 & 5.2 & 34.7 & 0.8 & 0.2 & 0.0 & 99.3 & 0.923 \\
\hline & Gt & 9 & 41.1 & 0.7 & 19.8 & 2.0 & 8.1 & 20.6 & 5.2 & 0.1 & 0.0 & 97.6 & 0.818 \\
\hline & L (100\%) & 22 & 38.6 & 3.5 & 5.9 & 0.4 & 13.8 & 25.3 & 11.1 & 0.5 & 0.9 & 100.0 & 0.766 \\
\hline \multirow[t]{4}{*}{ OD1053 } & $\mathrm{Ol}$ & 36 & 41.1 & 0.0 & 0.0 & 0.1 & 7.4 & 49.6 & 0.0 & 0.0 & 0.0 & 98.3 & 0.922 \\
\hline & $\mathrm{MgPx}$ & 31 & 55.3 & 0.0 & 2.2 & 0.4 & 5.0 & 33.0 & 0.6 & 0.1 & 0.0 & 96.8 & 0.921 \\
\hline & Gt & 4 & 42.3 & 0.3 & 19.5 & 2.9 & 7.1 & 23.0 & 3.6 & 0.0 & 0.1 & 98.8 & 0.852 \\
\hline & L (100\%) & 29 & 38.1 & 1.8 & 6.5 & 0.4 & 12.7 & 27.0 & 11.1 & 1.4 & 1.0 & 100.0 & 0.792 \\
\hline \multirow[t]{3}{*}{ OD1050 } & $\mathrm{Ol}$ & 29 & 41.4 & 0.0 & 0.0 & 0.1 & 7.1 & 50.3 & 0.1 & 0.1 & 0.0 & 99.1 & 0.927 \\
\hline & $\mathrm{MgPx}$ & 19 & 57.9 & 0.0 & 1.3 & 0.6 & 4.0 & 35.3 & 0.4 & 0.1 & 0.0 & 99.6 & 0.941 \\
\hline & L (100\%) & 52 & 43.2 & 0.9 & 6.2 & 0.6 & 11.1 & 31.1 & 5.7 & 0.7 & 0.4 & 100.0 & 0.833 \\
\hline \multirow[t]{3}{*}{ OD1045 } & $\mathrm{Ol}$ & 28 & 42.1 & 0.0 & 0.0 & 0.2 & 5.7 & 52.3 & 0.0 & 0.2 & 0.0 & 100.6 & 0.943 \\
\hline & $\mathrm{MgPx}$ & 2 & 58.6 & 0.1 & 1.1 & 0.5 & 3.4 & 36.5 & 0.4 & 0.2 & 0.0 & 100.8 & 0.950 \\
\hline & $L(100 \%)$ & 70 & 46.8 & 0.7 & 4.5 & 0.6 & 9.5 & 31.7 & 4.6 & 1.3 & 0.2 & 100.0 & 0.856 \\
\hline \multirow[t]{2}{*}{ OD1082 } & $\mathrm{Ol}$ & 29 & 40.8 & 0.0 & 0.0 & 0.2 & 5.3 & 51.9 & 0.1 & 0.7 & 0.0 & 99.0 & 0.946 \\
\hline & L (100\%) & 71 & 46.3 & 0.8 & 5.5 & 0.6 & 9.0 & 31.5 & 4.5 & 1.6 & 0.3 & 100.0 & 0.862 \\
\hline OD1087 & L (100\%) & 100 & 43.5 & 0.7 & 5.5 & 0.4 & 9.6 & 35.7 & 3.7 & 0.6 & 0.2 & 100.0 & 0.869 \\
\hline \multicolumn{14}{|l|}{$6.0 \mathrm{GPa}$} \\
\hline \multirow[t]{6}{*}{ OD1080 } & $\mathrm{Ol}$ & & 42.4 & 0.1 & 0.0 & 0.0 & 6.4 & 52.4 & 0.0 & 0.7 & 0.0 & 102.1 & 0.936 \\
\hline & $\mathrm{MgPx}$ & & 58.7 & 0.1 & 0.2 & 0.1 & 4.5 & 36.7 & 0.5 & 0.8 & 0.1 & 101.5 & 0.936 \\
\hline & Gt & & 42.4 & 0.4 & 18.1 & 1.2 & 10.7 & 20.7 & 6.4 & 0.7 & 0.0 & 100.6 & 0.775 \\
\hline & $\mathrm{CaPx}$ & & 55.4 & 0.2 & 1.2 & 0.3 & 4.5 & 18.1 & 19.0 & 2.4 & 0.0 & 101.2 & 0.879 \\
\hline & FeTi & & 1.2 & 15.3 & 0.8 & 2.2 & 62.0 & 3.8 & 0.2 & 0.4 & 0.0 & 86.0 & \\
\hline & L & $<5$ & & & & & & & & & & & \\
\hline \multirow[t]{4}{*}{ OD1065 } & $\mathrm{Ol}$ & 21 & 40.7 & 0.0 & 0.2 & 0.1 & 7.2 & 50.6 & 0.0 & 0.7 & 0.0 & 99.5 & 0.926 \\
\hline & $\mathrm{MgPx}$ & 41 & 57.0 & 0.0 & 1.0 & 0.2 & 4.7 & 36.0 & 0.5 & 0.8 & 0.0 & 100.3 & 0.932 \\
\hline & Gt & 9 & 42.2 & 0.3 & 18.7 & 2.3 & 8.1 & 24.9 & 2.1 & 0.7 & 0.0 & 99.2 & 0.847 \\
\hline & L (100\%) & 29 & 33.0 & 1.4 & 3.8 & 0.3 & 14.5 & 34.3 & 9.7 & 2.2 & 0.9 & 100.0 & 0.808 \\
\hline \multirow[t]{4}{*}{ OD1079 } & $\mathrm{Ol}$ & 21 & 41.0 & 0.0 & 0.0 & 0.1 & 6.7 & 51.0 & 0.0 & 0.7 & 0.0 & 99.5 & 0.932 \\
\hline & $\mathrm{MgPx}$ & 26 & 57.9 & 0.1 & 0.9 & 0.3 & 4.1 & 36.4 & 0.5 & 0.8 & 0.0 & 100.9 & 0.941 \\
\hline & Gt & 2 & 43.1 & 0.3 & 19.7 & 2.7 & 5.4 & 25.4 & 1.9 & 0.7 & 0.0 & 99.2 & 0.893 \\
\hline & L (100\%) & 52 & 41.3 & 1.2 & 5.2 & 0.5 & 11.2 & 33.2 & 5.7 & 1.4 & 0.2 & 100.0 & 0.841 \\
\hline \multirow[t]{2}{*}{ OD1063 } & $\mathrm{Ol}$ & 28 & 40.9 & 0.0 & 0.0 & 0.0 & 6.7 & 51.2 & 0.1 & 0.6 & 0.0 & 99.6 & 0.932 \\
\hline & $\mathrm{MgPx}$ & 21 & 57.7 & 0.0 & 1.0 & 0.3 & 3.7 & 36.0 & 0.6 & 0.8 & 0.0 & 100.2 & 0.94 \\
\hline
\end{tabular}


Table 3 Modal and chemical compositions of experimental liquid and residual mineral phases in pyrolite +2 wt.\% $\mathrm{H}_{2} \mathrm{O}$ (Continued)

\begin{tabular}{|c|c|c|c|c|c|c|c|c|c|c|c|c|c|}
\hline & $\mathrm{Gt}$ & 1 & 43.4 & 0.5 & 19.3 & 2.7 & 5.9 & 24.6 & 3.2 & 0.6 & 0.0 & 100.2 & 0.881 \\
\hline & L (100\%) & 50 & 43.2 & 0.9 & 5.1 & 0.5 & 11.1 & 30.6 & 7.0 & 1.2 & 0.3 & 100.0 & 0.831 \\
\hline \multirow[t]{2}{*}{ OD1095 } & $\mathrm{Ol}$ & 16 & 42.1 & 0.0 & 0.0 & 0.1 & 4.7 & 53.7 & 0.0 & 0.0 & 0.0 & 100.7 & 0.953 \\
\hline & L (100\%) & 84 & 45.5 & 0.5 & 4.7 & 0.6 & 8.7 & 34.6 & 4.0 & 1.3 & 0.2 & 100.0 & 0.877 \\
\hline OD1092 & L (100\%) & 100 & 41.7 & 0.7 & 4.9 & 0.6 & 9.1 & 37.5 & 3.6 & 1.6 & 0.2 & 100.0 & 0.880 \\
\hline OD1088 & L (100\%) & 100 & 47.3 & 0.4 & 4.0 & 0.5 & 8.0 & 35.4 & 2.7 & 1.6 & 0.1 & 100.0 & 0.887 \\
\hline \multicolumn{14}{|l|}{$8.0 \mathrm{GPa}$} \\
\hline \multirow[t]{5}{*}{ OD1086 } & $\mathrm{Ol}$ & & 40.8 & 0.1 & 0.0 & 0.1 & 8.6 & 49.9 & 0.0 & 0.7 & 0.0 & 100.2 & 0.912 \\
\hline & $\mathrm{MgPx}$ & & 56.5 & 0.0 & 0.7 & 0.2 & 5.1 & 33.3 & 1.6 & 1.1 & 0.1 & 98.6 & 0.920 \\
\hline & Gt & & 43.7 & 1.3 & 17.3 & 1.9 & 7.4 & 23.3 & 4.6 & 0.7 & 0.0 & 100.2 & 0.848 \\
\hline & CaPx & & 56.1 & 0.1 & 1.6 & 0.4 & 5.3 & 23.6 & 11.2 & 1.9 & 0.1 & 100.2 & 0.889 \\
\hline & L & $<5$ & & & & & & & & & & & \\
\hline \multirow[t]{4}{*}{ OD1058 } & $\mathrm{Ol}$ & 14 & 42.4 & 0.0 & 0.0 & 0.1 & 4.9 & 52.8 & 0.1 & 0.1 & 0.0 & 100.4 & 0.950 \\
\hline & $\mathrm{MgPx}$ & 6 & 59.2 & 0.0 & 0.7 & 0.2 & 3.1 & 36.8 & 0.5 & 0.1 & 0.0 & 100.6 & 0.955 \\
\hline & Gt & 4 & 45.5 & 0.6 & 16.9 & 1.9 & 5.7 & 26.5 & 2.3 & 0.1 & 0.0 & 99.5 & 0.892 \\
\hline & L (100\%) & 76 & 45.5 & 0.6 & 3.3 & 0.4 & 9.5 & 35.9 & 3.9 & 0.6 & 0.2 & 100.0 & 0.871 \\
\hline
\end{tabular}

Ol, olivine; MgPx, Mg-rich orthopyroxene; Gt, garnet; CaPx, clinopyroxene; FeTi, Fe- and Ti-bearing hydroxide; L, liquid; (100\%), 100\% normalized chemical composition. $\mathrm{FeO}^{*}$, total iron is listed as $\mathrm{FeO}$.

Table 4 Chemical compositions of experimental and residual mineral phases in pyrolite +8 wt.\% $\mathrm{H}_{2} \mathrm{O}$

\begin{tabular}{|c|c|c|c|c|c|c|c|c|c|c|c|c|}
\hline Run no. & & $\mathrm{SiO}_{2}$ (wt.\%) & $\mathrm{TiO}_{2}$ & $\mathrm{Al}_{2} \mathrm{O}_{3}$ & $\mathrm{Cr}_{2} \mathrm{O}_{3}$ & $\mathrm{FeO}^{*}$ & $\mathrm{MgO}$ & $\mathrm{CaO}$ & $\mathrm{Na}_{2} \mathrm{O}$ & $\mathrm{K}_{2} \mathrm{O}$ & Total & Mg\# \\
\hline \multicolumn{13}{|l|}{$3.0 \mathrm{GPa}$} \\
\hline \multirow[t]{2}{*}{ OD1085 } & Ol & 40.3 & 0.0 & 0.0 & 0.1 & 7.8 & 50.0 & 0.1 & 0.7 & 0.0 & 99.1 & 0.920 \\
\hline & $\mathrm{MgPx}$ & 56.1 & 0.0 & 1.4 & 0.9 & 4.9 & 35.1 & 0.3 & 0.8 & 0.0 & 99.6 & 0.927 \\
\hline \multicolumn{13}{|l|}{$4.5 \mathrm{GPa}$} \\
\hline \multirow[t]{3}{*}{ OD1022 } & $\mathrm{Ol}$ & 40.9 & 0.0 & 0.0 & 0.1 & 8.4 & 50.0 & 0.0 & 0.2 & 0.0 & 99.6 & 0.914 \\
\hline & $\mathrm{MgPx}$ & 56.9 & 0.1 & 0.8 & 0.3 & 4.9 & 35.4 & 0.4 & 0.3 & 0.0 & 99.0 & 0.928 \\
\hline & Gt & 41.2 & 0.5 & 20.4 & 2.2 & 7.9 & 21.9 & 3.8 & 0.1 & 0.0 & 98.6 & 0.832 \\
\hline \multirow[t]{2}{*}{ OD1053 } & Ol & 41.2 & 0.0 & 0.0 & 0.1 & 5.8 & 50.9 & 0.0 & 0.0 & 0.0 & 98.1 & 0.940 \\
\hline & $\mathrm{MgPx}$ & 55.6 & 0.1 & 1.4 & 0.8 & 4.1 & 35.4 & 0.3 & 0.0 & 0.0 & 97.5 & 0.939 \\
\hline \multirow[t]{2}{*}{ OD1050 } & Ol & 41.7 & 0.14 & 0.0 & 0.2 & 5.1 & 51.6 & 0.0 & 0.1 & 0.0 & 98.8 & 0.948 \\
\hline & $\mathrm{MgPx}$ & 58.3 & 0.0 & 0.5 & 0.4 & 3.2 & 36.1 & 0.2 & 0.1 & 0.0 & 99.0 & 0.952 \\
\hline OD1045 & Ol & 41.8 & 0.0 & 0.0 & 0.1 & 4.9 & 52.2 & 0.1 & 0.1 & 0.0 & 99.3 & 0.950 \\
\hline \multicolumn{13}{|l|}{$6 \mathrm{GPa}$} \\
\hline \multirow[t]{4}{*}{ OD1080 } & Ol & 41.54 & 0.0 & 0.0 & 0.0 & 6.0 & 52.2 & 0.0 & 0.7 & 0.0 & 100.5 & 0.939 \\
\hline & $\mathrm{MgPx}$ & 57.7 & 0.0 & 0.7 & 0.0 & 4.2 & 36.5 & 0.4 & 0.8 & 0.0 & 100.5 & 0.940 \\
\hline & Gt & 41.6 & 0.5 & 17.9 & 1.3 & 10.4 & 21.4 & 4.9 & 0.7 & 0.0 & 98.6 & 0.786 \\
\hline & $\mathrm{FeTi}$ & 2.3 & 12.9 & 1.6 & 2.5 & 61.4 & 3.5 & 0.5 & 0.3 & 0.0 & 85.0 & \\
\hline \multirow[t]{2}{*}{ OD1065 } & $\mathrm{MgPx}$ & 56.7 & 0.1 & 1.0 & 0.2 & 3.2 & 36.8 & 0.4 & 0.9 & 0.0 & 99.2 & 0.954 \\
\hline & Gt & 43.5 & 0.2 & 19.2 & 2.4 & 5.8 & 26.3 & 2.0 & 0.7 & 0.0 & 100.0 & 0.891 \\
\hline OD1079 & $\mathrm{MgPx}$ & 57.8 & 0.1 & 0.7 & 0.3 & 3.0 & 36.9 & 0.2 & 0.8 & 0.0 & 99.9 & 0.956 \\
\hline \multicolumn{13}{|l|}{$8 \mathrm{GPa}$} \\
\hline \multirow[t]{2}{*}{ OD1086 } & $\mathrm{MgPx}$ & 58.6 & 0.1 & 0.5 & 0.3 & 3.0 & 37.1 & 0.3 & 0.8 & 0.0 & 100.6 & 0.957 \\
\hline & Gt & 45.0 & 0.2 & 17.9 & 2.4 & 4.9 & 27.4 & 1.1 & 0.6 & 0.0 & 99.4 & 0.910 \\
\hline
\end{tabular}

$\mathrm{Ol}$, olivine; MgPx, Mg-rich orthopyroxene; Gt, garnet; FeTi, Fe- and Ti-bearing hydroxide. FeO*, total iron is listed as FeO. 

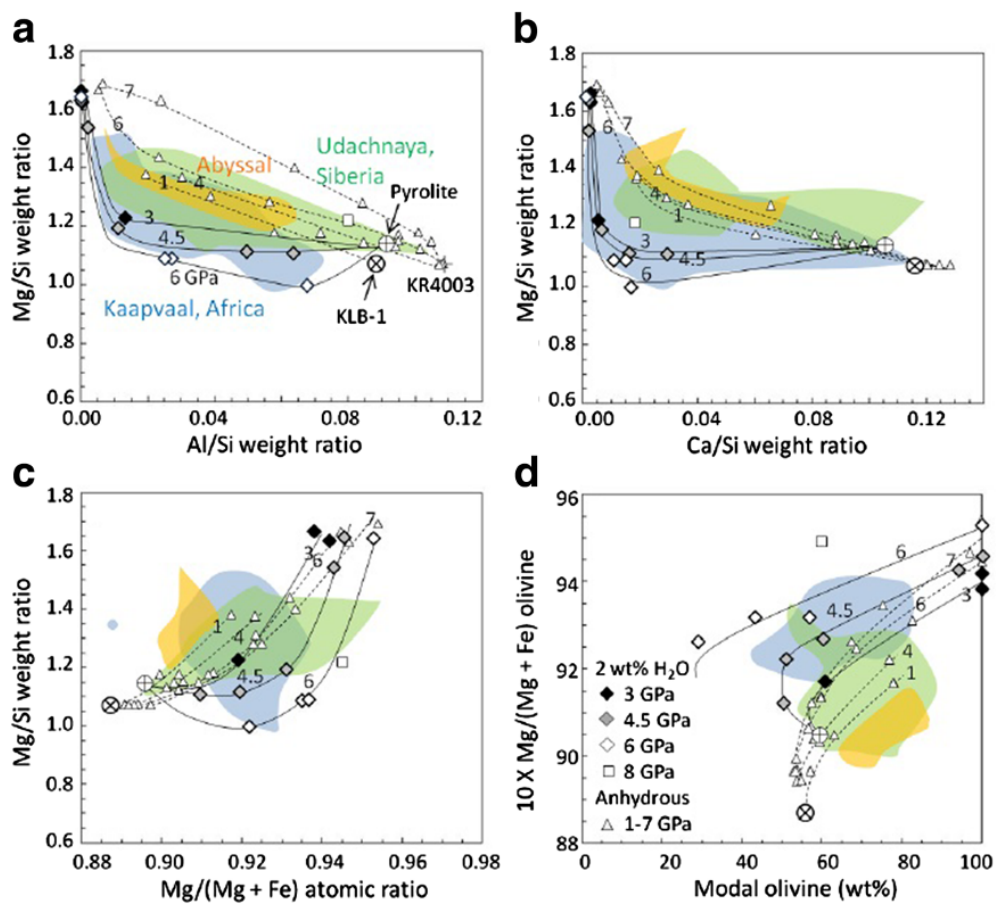

Figure 5 Bulk chemistry $(a, b, c)$ and relation between $\mathrm{Mg} /(\mathrm{Mg}+\mathrm{Fe})$ atomic percentages and modal compositions of olivine (d). They are in residues produced by hydrous melting experiments with $2 \mathrm{wt} . \% \mathrm{H}_{2} \mathrm{O}$, compared with the result of anhydrous partial melting of KLB-1 at 1.0 GPa (Matsukage and Kubo 2003) and KR4003 at 4 to 7 GPa (Walter 1998). The range of abyssal, Kaapvaal, and Siberian peridotites are the same as in Figure 1. Solid and dashed curves show residual trends of hydrous and anhydrous conditions, respectively.

Seismological observations have revealed a high-velocity structure with a maximum $V_{\mathrm{S}}$ anomaly of about $8 \%$ in the root of the Archean cratons (Jordan 1981; Yoshizawa and Kennett 2004; Begg et al. 2009). Electrical conductivity in depth ranges of 100 to $250 \mathrm{~km}$ is markedly lower for the continental root than it is in oceanic regions (Hirth et al. 2000). As discussed by Hirth et al. (2000), these geophysical results indicate that the Archean lithospheric mantle contains less water than the oceanic mantle at depths of about 100 to $250 \mathrm{~km}$. We speculate that the Archean mantle had spatial (or both spatial and temporal) heterogeneity in its water content (Jung and Karato 2001) and that the extensive partial melting occurred in areas with higher water content to form an $\mathrm{SiO}_{2}$-rich and $\mathrm{MgO}$-rich cratonic mantle. $\mathrm{H}_{2} \mathrm{O}$ would be highly partitioned into the liquid phase if extensive hydrous partial melting and melt extraction had occurred in the upper mantle. Consequently, a nearly dry mantle residue would be left behind to form the dry cratonic peridotites. This model seems to provide a reasonable explanation for the high $V_{\mathrm{S}}$ and low conductivity of the old continental roots. The dry cratonic mantle might be stabilized against convective instability for a long time because of its high viscosity (e.g., Eaton and Perry 2013).

\section{Competing interests}

The authors declare that they have no competing interests.

\section{Authors' contributions}

KNM designed the research methodology, performed the high-pressure experiments and chemical analysis, and wrote the paper. TK synthesized the starting materials. Both authors read and approved the final manuscript.

\section{Acknowledgements}

We thank Y Nishihara for discussions and M lehisa for the help in the experiments. The comments made by anonymous reviewers are also appreciated. This study was supported by a grant-in-aid for scientific research in innovative areas (21109004).

\section{Author details}

${ }^{1}$ Graduate School of Human and Environmental Studies, Kyoto University, Yoshida-Nihonmatsu-cho, Sakyo-ku, Kyoto 606-8501, Japan. ${ }^{2}$ Graduate School of Sciences and Engineering, Ehime University, Bunkyo-cho 2-5, Matsuyama 790-8577, Japan.

Received: 7 October 2013 Accepted: 11 April 2014

Published: 1 May 2014

\section{References}

Arai S (1994) Characterization of spinel peridotites by olivine-spinel compositional relationships: review and interpretation. Chem Geol 113:191-204

Arai S, Matsukage K (1996) Petrology of the gabbro-troctolite-peridotite complex from Hess Deep, equatorial Pacific: implications for mantle-melt interaction within the oceanic lithosphere, Proc. Ocean Drill. Program, Sci. Results 147:135-155

Baker M, Stolper EM (1994) Determining the composition of high-pressure mantle melts using diamond aggregates. Geochim Cosmochim Acta 58:2811-2827 
Begg GC, Griffin WL, Natapov LM, O'Reilly SY, Grand SP, O'Neill CJ, Hronsky JMA, Poudjom-Djomani Y, Swain CJ, Deen T, Bowden P (2009) The lithospheric architecture of Africa: seismic tomography, mantle petrology, and tectonic evolution. Geosphere 5:23-50, doi:10.1130/GES00179.1

Boyd FR (1989) Compositional distinction between oceanic and cratonic lithosphere. Earth Planet Sci Lett 96:15-26

Boyd FR, Pokhilenko NP, Pearson DG, Mertzman SA, Sobolev NV, Finger LW (1997) Composition of the Siberian cratonic mantle: evidence from Udachnaya peridotite xenoliths. Contrib Mineral Petrol 128:228-246

Boyd FR, Pearson DG, Nixon PH, Mertzman SA (1993) Low-calcium garnet harzburgites from southern Africa: their relations to craton structure and diamond crystallization. Contrib Mineral Petrol 113:352-366

Carswell DA, Clarke DB, Mitchel RH (1979) The petrology and geochemistry of ultramafic nodules from pipe200, northern Lesotho. In: Boyd FR, Meye HOA (eds) Mantle samples: inclusion in kimberlites and othervolcanics. Wiley, New York, pp 127-144

Cox KG, Gurney J, Harth B (1973) Xenoliths from the Matsoku pipe. In: Lesotho K, Nixon PH (eds) Lesotho kimberlite. Lesotho National Development Corporation, Maseru, pp 76-100

Dick HJB (1989) Abyssal peridotites, very slow spreading ridges and ocean ridge magmatism. In: Saunders AD, Norry MJ (eds) Magmatism in the ocean basins. Geol Soc Spec Publ, pp 71-105

Dick HJB, Natland JH (1996) Late-stage melt evolution and transport in the shallow mantle beneath the east Pacific rise. Proc Ocean Drill Program Sci Results 147:103-134

Dick HJB, Fisher RL, Bryan WB (1984) Mineralogical variability of the uppermost mantle along mid-ocean ridges. Earth Planet Sci Lett 69:88-106

Doucet LS, lonov DA, Golovin AV, Pokhilenko LN (2012) Depth, degrees and tectonic settings of mantle melting during craton formation: inferences from major and trace element compositions of spinel harzburgite xenoliths from Udachnaya kimberlite, central Siberia. Earth Planet Sci Lett 359-360:206-218

Doucet LS, Ionov DA, Golovin AV (2013) The origin of coarse garnet peridotites in cratonic lithosphere: new data on xenoliths from the Udachnaya kimberlite, central Siberia. Contrib Mineral Petrol 165:1225-1242

Eaton DW, Perry KC (2013) Ephemeral isopycnicity of cratonic mantle keels. Nat Geosci 6:967-970

Gasparik T (1990) A thermodynamic model for the enstatite-diopside join. Am Min 75:1080-1091

Gibson SA, Malarkey J, Day JA (2008) Melt depletion and enrichment beneath the western Kaapvaal craton: evidence from Finsch peridotite xenoliths. J Petrol 49:1817-1852

Goncharov AG, Ionov DA, Doucet LS, Pokhilenko LN (2012) Thermal state, oxygen fugacity and C-O-H fluid speciation in cratonic lithospheric mantle: new data on peridotite xenoliths from the Udachnaya kimberlite, Siberia. Earth Planet Sci Lett 357-358:99-110

Hervig RL, Smith JV, Steele IM, Dawson JB (1980) Fertile and barren Al-Cr-spinel harzburgites from the upper mantle: ion and electron probe analyses of trace elements in olivine and orthopyroxene: relation to Iherzolites. Earth Planet Sci Lett 50:41-58

Herzberg C (1999) Phase equilibrium constraints on the formation of cratonic mantle. In: Fei Y, Bertka CM, Mysen BO (eds) Mantle petrology: field observations and high pressure experimentation: a tribute to Francis R. (Joe) Boyd. Spec Publ Geochem Soc 6., pp 241-257

Hirose K, Kawamoto T (1995) Hydrous partial melting of Iherzolite at 1 GPa: the effect of $\mathrm{H}_{2} \mathrm{O}$ on the genesis of basaltic magmas. Earth Planet Sci Lett 133:463-473

Hirth G, Evans RL, Chave AD (2000) Comparison of continental and oceanic mantle electrical conductivity: is the Archean lithosphere dry? Geochem Geophys Geosyst 1:2000GC000048

Inoue T (1994) Effect of water on melting phase relations and melt composition in the system $\mathrm{Mg}_{2} \mathrm{SiO}_{4}-\mathrm{MgSiO}_{3}-\mathrm{H}_{2} \mathrm{O}$ up to $15 \mathrm{GPa}$. Phys Earth Planet Interiors 85:237-263

Jagoutz E, Palme H, Baggenhausen H, Blum K, Cendales M, Dreibus G, Spettel B, Lorenz V, Wänke H (1979) The abundances of major, minor and trace elements in the Earth's mantle as derived from primitive ultramafic nodules. Proc Lunar Planet Sci Conf 10th 2:2031-2050

Jordan TH (1981) Continents as a chemical boundary layer. Philos Trans R Soc London, Ser A 301:359-373

Jung H, Karato S (2001) Water-induced fabric transitions in olivine. Science 293:1460-1463
Katayama I, Suyama Y, Ando J, Komiya T (2009) Mineral chemistry and P-T condition of granular and sheared peridotite xenoliths from Kimberlite, South Africa: origin of the textural variation in the cratonic mantle. Lithos 109:333-340

Kawamoto TKN, Matsukage K, Mibe M, Isshiki K, Nishimura N, Ishimatsu OS (2004) $\mathrm{Mg} / \mathrm{Si}$ ratios of aqueous fluids coexisting with forsterite and enstatite based on the phase relations in the $\mathrm{Mg}_{2} \mathrm{SiO}_{4}-\mathrm{SiO}_{2}-\mathrm{H}_{2} \mathrm{O}$ system. Am Mineral 89:1433-1437

Kawasaki T (1987) Palaeogeotherms: olivine-orthopyroxene-garnet geothermometry and geobarometry. Lithos 20:263-278

Kawasaki T (2001) Experimental investigation of mixing properties of (Ca, Mg, Fe) 2SiO4 olivine: $\mathrm{Fe}-\mathrm{Mg}$ exchange with Ca-rich clinopyroxene and phase relations in olivine quadrilateral. J Mineral Petrol Sci 96:217-242

Kelemen PB, Hart SR, Bernstein S (1998) Silica enrichment in the continental upper mantle via melt/rock reaction. Earth Planet Sci Lett 164:387-406

Litasov K, Ohtani E (2002) Phase relations and melt compositions in CMASpyrolite- $\mathrm{H}_{2} \mathrm{O}$ system up to $25 \mathrm{GPa}$. Phys Earth Planet Inter 134:105-127

Matsukage KN, Kubo K (2003) Chromian spinel during melting experiments of dry peridotite (KLB-1) at 1.0-2.5 GPa. Am Mineral 88:1271-1278

Matsukage KN, Nagayo Y, Whitaker ML, Takahashi E, Kawasaki T (2013) Melting of the Martian mantle from 1.0 GPa to 4.5 GPa. J Mineral Petrol Sci 108:201-214

Matsukage KN, Nishihara Y, Karato S (2005) Seismological signature of chemical differentiation of the Earth's upper mantle. J Geophys Res 110, B12305. doi:10.1029/2004JB003504

Mibe K, Fujii T, Yasuda A (2002) Composition of aqueous fluid coexisting with mantle minerals at high pressure and its bearing on the differentiation of the Earth's mantle. Geochim Cosmochim Acta 66:2273-2285

Michael PJ, Bonatti E (1985) Peridotite composition from the North Atlantic: regional and tectonic variations and implications for partial melting. Earth Planet Sci Lett 73:91-104

Nixon PH, Boyd FR (1973) Petrogenesis of the granular and sheared ultrabasic nodule suite in kimberlites. In: Nixon PH (ed) Lesotho kimberlite. Lesotho National Development Corporation, Maseru, pp 48-56

Ohtani E, Mibe K, Kato T (1996) Origin of cratonic peridotite and komatiite: evidence for melting in the wet Archean mantle. Proc Jpn Acad Ser B Phys Biol Sci 72:113-117

Pearson DG, Wittig N (2013) Formation of Archaean continental lithosphere and its diamonds: the root of the problem. J Geol Soc 165:895-914

Ringwood AE (1966) The chemical composition and origin of the Earth. In: Hurley PM (ed) Advances in earth sciences. MIT Press, Cambridge, Mass, pp 287-356

Walter MJ (1998) Melting of garnet peridotite and the origin of komatiite and depleted lithosphere. J Petrol 39:29-60

Yoshizawa K, Kennett BLN (2004) Multimode surface wave tomography for the Australian region using a three-stage approach incorporating finite frequency effects. J Geophys Res 109:B2310. doi:10.1029/2002JB002254

\section{doi:10.1186/1880-5981-66-29}

Cite this article as: Matsukage and Kawasaki: Hydrous origin of the continental cratonic mantle. Earth, Planets and Space 2014 66:29.

\section{Submit your manuscript to a SpringerOpen ${ }^{\odot}$ journal and benefit from:}

- Convenient online submission

- Rigorous peer review

- Immediate publication on acceptance

- Open access: articles freely available online

High visibility within the field

- Retaining the copyright to your article

Submit your next manuscript at $>$ springeropen.com 